\title{
The changing trend of mortality caused by gastrointestinal cancers in Iran during the years 2006-2010
}

\author{
Fatemeh SALEHI ${ }^{1}$, Ali AHMADI ${ }^{1,2}$, Seyede Soghra AHMADI SOODEJANI ${ }^{1}$ and Milad SHAHINI SHAMS ABADI ${ }^{3}$
}

\begin{abstract}
Background - Cancers are one of the most important causes of death in the world. According to their high incidence and mortality, gastrointestinal cancers have particular importance among other cancers. Objective - Therefore, this study was conducted to investigate the mortality change trends of gastrointestinal cancers in Iran. Methods - This study was performed by analyzing the reported mortality data in 29 provinces of Iran in 2006-2010. Mortality trend of gastrointestinal cancers was drawn for both sexes in the study years and disaggregated by age groups and their frequency distribution. The WinPepi software was used for analysis. Results - In the years 2006-2010, the mortality rate of, gastric, colorectal, liver and pancreatic cancers, has significantly increased. Totally, gastrointestinal mortality is higher in men than women. Also, the results showed that by increasing age, death from these cancers also increased. Conclusion - The most important causes of death from gastrointestinal cancers were gastric, liver and colorectal cancers in Iran and because of their increasing trend in the country, performing preventive interventions for the cancers' risk factors is necessary.
\end{abstract}

HEADINGS - Gastrointestinal Neoplasms, mortality. Age factors. Sex factors. Middle East.

\section{INTRODUCTION}

Cancers are one of the most important causes of death in the world ${ }^{(1)}$. More than $70 \%$ of these deaths occur in developing and undeveloped countries ${ }^{(2)}$. Gastrointestinal cancers include gastric, esophagus, colorectal, small intestine, lips, mouth and pharynx, liver, biliary system and pancreas cancers ${ }^{(3)}$, which are especially important due to their high incidence and mortality among other cancers $^{(4,5)}$. Gastric cancer is the $2 \mathrm{nd}$, liver cancer is the $3 \mathrm{rd}$ and esophagus cancer is the $6^{\text {th }}$ cause of death among cancers in the world ${ }^{(6)}$. Cancer is the 3 rd cause of death after cardiovascular disease and accidents in $\operatorname{Iran}^{(7)}$. The most important causes of death caused by gastrointestinal cancers in Iran, have been gastric, liver, esophagus and colorectal cancers ${ }^{(8)}$.

There are different reports about each one of gastrointestinal cancers' mortality in the world. The number of deaths caused by gastric cancer in the western countries and even in the countries with high incidence of gastric cancers like Japan, Korea, Colombia, Ecuador and Russia has been decreased ${ }^{(9)}$. However, the mortality caused by liver cancer has had an increasing rate in Mexico and USA in 2000 to $2006^{(10)}$. The deaths from colorectal cancer have been decreased in both sexes in some countries ${ }^{(11)}$. Also during the years 1992 to 2002, an increasing trend of death caused by pancreatic cancer has been observed in Romania, Albania, Spain, Croatia and Korea ${ }^{(12)}$, while the death trend was decreased in men in Ireland, England, Switzerland, Austria and Poland countries ${ }^{(13)}$. The trend of deaths from gastric cancer has been decreasing in the years 1970 to 2000 in some of the Latin American countries like Colombia, Venezuela, Ecuador, Costa Rica and increasing in some others like Mexico, Canada and the United States ${ }^{(14)}$. On the basis of WHO report in the years 2008 and 2012, generally, a decreasing trend of death from gastrointestinal cancers has been shown except for colorectal and pancreatic cancers which have had a small increasing trend all over the world ${ }^{(6,15)}$. Improvement of lifestyle like decreased salt intake, keeping food in the refrigerator and also decreased prevalence of $H$. pylori, is somewhat related to the decreasing trend of gastric cancer ${ }^{(16)}$. Reduction in death trend caused by colorectal cancer in some countries has been due to its screening and therapy developments ${ }^{(11)}$. Also, it has been observed that alcohol usage and hepatitis infection correlate with increasing deaths from liver cancer ${ }^{(17)}$. Changes in diagnostic methods ${ }^{(13)}$ and smoking ${ }^{(18)}$ are correlated with the changed trend of deaths from pancreatic cancer in different parts of the world.

For planning in the health care system, providing sufficient fund for necessary instruments, and training expert people, knowledge about mortality is necessary. In Iran, gastrointestinal cancers are the cause of repeated visits and re-hospitalization and lead to high costs imposed on the patient ${ }^{(8)}$. Until now, we have had no study determining the process of mortality caused by gastrointestinal cancers (separately in different parts of the gastrointestinal tract) in recent years in the country, so considering the fact that epidemiological information is the prerequisite of successful planning for decreasing death, the health centers need to know this information to find the right solution for cancer prevention. Therefore, this study was carried out aiming at studying mortality change trend caused by gastrointestinal cancer in Iran.

${ }^{1}$ Shahrekord University of Medical Sciences, Modeling in Health Research Center, Shahrekord, Iran. ${ }^{2}$ Shahrekord University of Medical Sciences, Department of Epidemiology and Biostatistics, 


\section{METHODS}

This cross-sectional study was performed by analyzing data of the published country report of mortality in 29 provinces in 20062010. The data were collected from information and technology management group center and applied research of the Ministry of Health and Medical Education from different sources including NOCR (Network for Oncology Communication and Research), cemeteries, hospitals and health centres. Their homogenization was done and for grouping them in 17 groups on the basis of mortality causes, we used ICD10 of World Health Organization ${ }^{(3)}$. In this study, the data of death caused by gastrointestinal cancers (ICD code: C15-C26) including gastric, esophagus, colorectal, small intestine, lips, mouth and pharynx, liver, pancreatic and biliary system were extracted from data for all causes of deaths.

The extracted information was checked on the basis of frequency, percentage of all deaths and also the number of deaths per one hundred thousand people divided by sex and age groups for existence of deaths from gastrointestinal cancers.

\section{Statistical analysis}

After checking the data and eliminating the missing data, we used Excel 2010 for analysis and WinPepi 2-1 for drawing figures and tables in order to determine the significance of the death trend change from gastrointestinal cancers during a 5-year period. Crude mortality rates for cancer diseases were calculated as the ratio of deaths due to cancers and the population of the provinces of Iran; standardized rates were calculated by the direct method as the ratio between total expected deaths in template of WinPepi analysis software.

\section{RESULTS}

Investigating the mortality caused by gastrointestinal cancer among per hundred thousand people during 2006-2010 in all ages and gender groups showed that the death from gastrointestinal cancer slightly increased from 23.86 in 2006 to 25.16 in 2010 (TABLE 1). Moreover, gastrointestinal cancer mortality rate was higher for male (FIGURE 1 and TABLE 1). The Gastrointestinal cancers mortality rate was changed from 29.72 in 2006 to 30.99 in 2010 in men and it was increased from 17.81 in 2006 to 19.18 in 2010 in women (TABLE 1), the trend of death from lips and mouth cancer did not have a significant increase between 2006 and $2010(P=0.95)$. Moreover, Esophagus cancer mortality rate did not have a significant increase in this time $(P=0.15)$ (TABLE 1 and 2$)$.

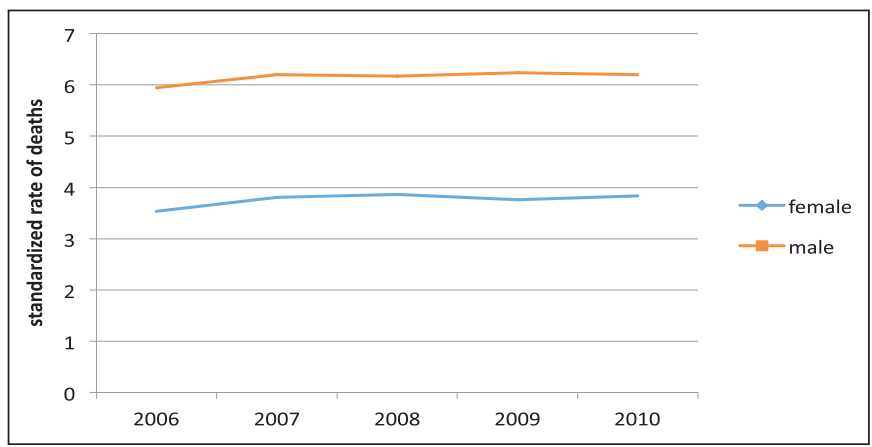

FIGURE 1. The trend of gastrointestinal cancers divided by gender in 29 provinces of Iran from 2006 to 2010.

TABLE 1 . Standardized death per 100,000 people (all ages) due to gastrointestinal cancers during the 2006 to 2010 by sex, separately in different parts of the gastrointestinal tract (Statistical significance was attributed to $P$ value $<.05$.)

\begin{tabular}{|c|c|c|c|c|c|c|c|c|c|c|c|c|c|c|c|c|c|}
\hline \multirow{2}{*}{ Cause of death } & \multirow{2}{*}{$\begin{array}{l}\text { ICD } \\
\text { code }\end{array}$} & \multicolumn{3}{|c|}{2006} & \multicolumn{3}{|c|}{2007} & \multicolumn{3}{|c|}{2008} & \multicolumn{3}{|c|}{2009} & \multicolumn{3}{|c|}{2010} & \multirow{2}{*}{$P$-value } \\
\hline & & Female & Male & Total & Female & Male & Total & Female & Male & Total & Female & Male & Total & Female & Male & Total & \\
\hline $\begin{array}{l}\text { Gastrointestinal } \\
\text { cancers }\end{array}$ & $\mathrm{C} 15-\mathrm{C} 26$ & 17.81 & 29.72 & 23.86 & 19.02 & 30.10 & 25.09 & 19.30 & 30.85 & 25.15 & 18.90 & 31.29 & 25.17 & 19.18 & 30.99 & 25.16 & $<0.001$ \\
\hline $\begin{array}{l}\text { Lips, mouth and } \\
\text { pharynx cancer }\end{array}$ & $\mathrm{C} 00-\mathrm{C} 14$ & 0.03 & 0.26 & 0.283 & 0.28 & 0.30 & 0.29 & 0.22 & 0.27 & 0.24 & 0.29 & 0.35 & 0.32 & 0.27 & 0.26 & 0.26 & 0.95 \\
\hline Esophagus cancer & $\mathrm{C} 15$ & 2.56 & 3.76 & 3.17 & 2.67 & 3.84 & 3.26 & 2.80 & 3.48 & 3.14 & 2.57 & 3.60 & 3.09 & 2.58 & 3.61 & 3.10 & 0.15 \\
\hline Gastric cancer & $\mathrm{C} 16$ & 7.64 & 14.71 & 11.23 & 7.93 & 15.47 & 11.75 & 7.44 & 15.09 & 11.31 & 7.49 & 14.78 & 11.18 & 7.53 & 14.51 & 11.06 & 0.02 \\
\hline $\begin{array}{l}\text { Small intestine } \\
\text { cancer }\end{array}$ & $\mathrm{C} 17$ & 1.19 & 1.74 & 1.47 & 1.21 & 1.63 & 1.42 & 1.24 & 1.87 & 1.56 & 1.27 & 1.92 & 1.60 & 1.25 & 1.96 & 1.61 & $<0.001$ \\
\hline Colon cancer & C18 & 1.40 & 2.01 & 1.71 & 1.75 & 2.35 & 2.06 & 1.91 & 2.51 & 2.21 & 1.74 & 2.58 & 2.16 & 1.79 & 2.49 & 2.15 & $<0.001$ \\
\hline Rectal cancer & C19-21 & 0.21 & 0.25 & 0.23 & 0.20 & 0.32 & 0.26 & 0.25 & 0.36 & 0.31 & 0.25 & 0.36 & 0.31 & 0.30 & 0.50 & 0.40 & $<0.001$ \\
\hline $\begin{array}{l}\text { Liver and bile system } \\
\text { cancer }\end{array}$ & $\mathrm{C} 22-\mathrm{C} 24$ & 3.81 & 5.73 & 4.78 & 4.22 & 5.85 & 5.04 & 4.41 & 5.84 & 5.14 & 4.09 & 6.06 & 5.09 & 4.61 & 6.11 & 5.37 & $<0.001$ \\
\hline Pancreas cancer & $\mathrm{C} 25$ & 0.70 & 1.25 & 0.98 & 0.77 & 1.22 & 0.10 & 1.02 & 1.42 & 1.22 & 0.96 & 1.41 & 1.19 & 0.83 & 1.55 & 1.19 & $<0.001$ \\
\hline $\begin{array}{l}\text { Others } \\
\text { Gastrointestinal } \\
\text { cancers }\end{array}$ & C26 & 0 & 0 & 0 & 0 & 0 & 0 & 0.01 & 0.01 & 0.01 & 0.01 & 0.01 & 0.01 & $<0.001$ & $<0.001$ & $<0.001$ & 0.023 \\
\hline
\end{tabular}

TABLE 2. Standardized death of gastric cancers per 100,000 people per year studied separately by age groups and sex

\begin{tabular}{|c|c|c|c|c|c|c|c|c|c|c|c|c|c|c|c|}
\hline \multirow{2}{*}{ Years } & \multicolumn{3}{|c|}{$<5$} & \multicolumn{3}{|c|}{$5-14$} & \multicolumn{3}{|c|}{$15-49$} & \multicolumn{3}{|c|}{$50-69$} & \multicolumn{3}{|c|}{$>70$} \\
\hline & Female & Male & Total & Female & Male & Total & Female & Male & Total & Female & Male & Total & Female & Male & Total \\
\hline 2006 & 1.25 & 2.27 & 1.78 & 0.08 & 0.27 & 0.18 & 4.03 & 5.89 & 4.97 & 61.43 & 100.88 & 80.98 & 267.32 & 430.68 & 353.63 \\
\hline 2007 & 1.54 & 2.17 & 1.87 & 0.11 & 0.19 & 0.15 & 4.02 & 6.39 & 5.22 & 64.39 & 99.39 & 81.64 & 295.71 & 470.19 & 388.52 \\
\hline 2008 & 0 & 0 & 0 & 0.18 & 0.22 & 0.20 & 4.01 & 5.78 & 4.90 & 64.27 & 99.91 & 81.81 & 302.03 & 479.57 & 395.77 \\
\hline 2009 & 1.68 & 1.43 & 1.55 & 0.11 & 0.17 & 0.14 & 3.80 & 6.03 & 4.93 & 60.66 & 101.98 & 80.99 & 302.03 & 484.63 & 397.69 \\
\hline 2010 & 1.65 & 2.10 & 1.88 & 0.13 & 0.15 & 0.14 & 3.98 & 5.85 & 4.92 & 59.83 & 97.34 & 78.28 & 307.65 & 497.08 & 406.08 \\
\hline$P$-value & 0.15 & 0.14 & 0.86 & 0.49 & 0.18 & 0.40 & 0.49 & 0.40 & 0.27 & 0.09 & 0.39 & 0.05 & $<0.001$ & $<0.001$ & $<0.001$ \\
\hline
\end{tabular}


However, other gastrointestinal cancers, including gastric, small intestine, colorectal, liver and pancreas, had a significant increase in this period (TABLE 1 and 2). The results showed that among gastrointestinal cancers, gastric cancer had the highest mortality rates (TABLE 2 and FIGURE 2). The lowest mortality of gastrointestinal cancers belongs to lips and mouth cancers (TABLE 2).

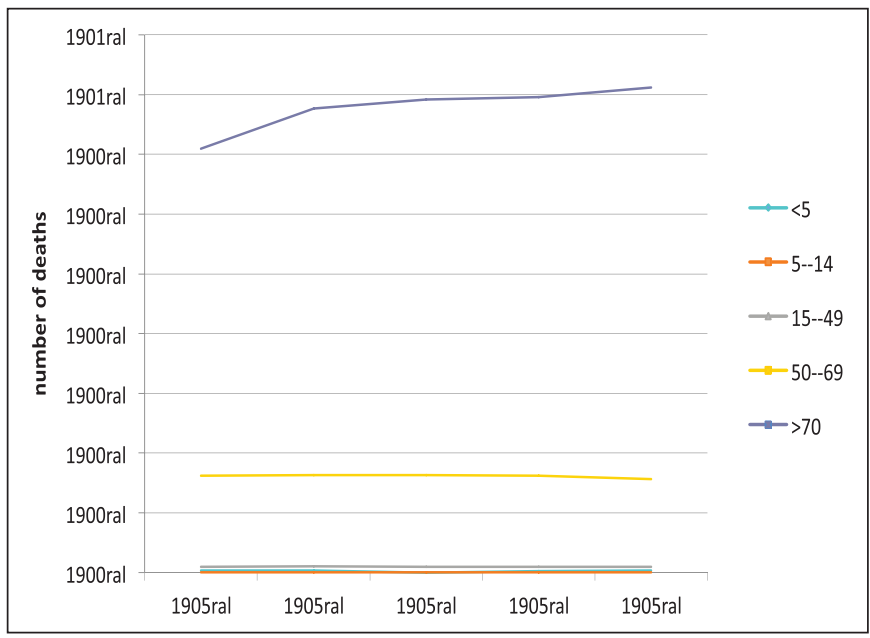

FIGURE 2. The trend of gastrointestinal cancers divided by age groups in 29 provinces of Iran from 2006 to 2010 , Separated in different age groups.

The calculation of mortality from gastrointestinal cancers in all the study year in age and gender groups showed that deaths from these cancers increased with aging. The mortality due to gastrointestinal cancers in the age groups under 5 and 5-14 years is the lowest rate while this trend increased with aging, so that the highest mortality observed was in more than 70 years old age groups. Also, its trend has had a significant increase since the year 2006 from 353.63 to 406.08 (TABLE 2 and FIGURE 3).

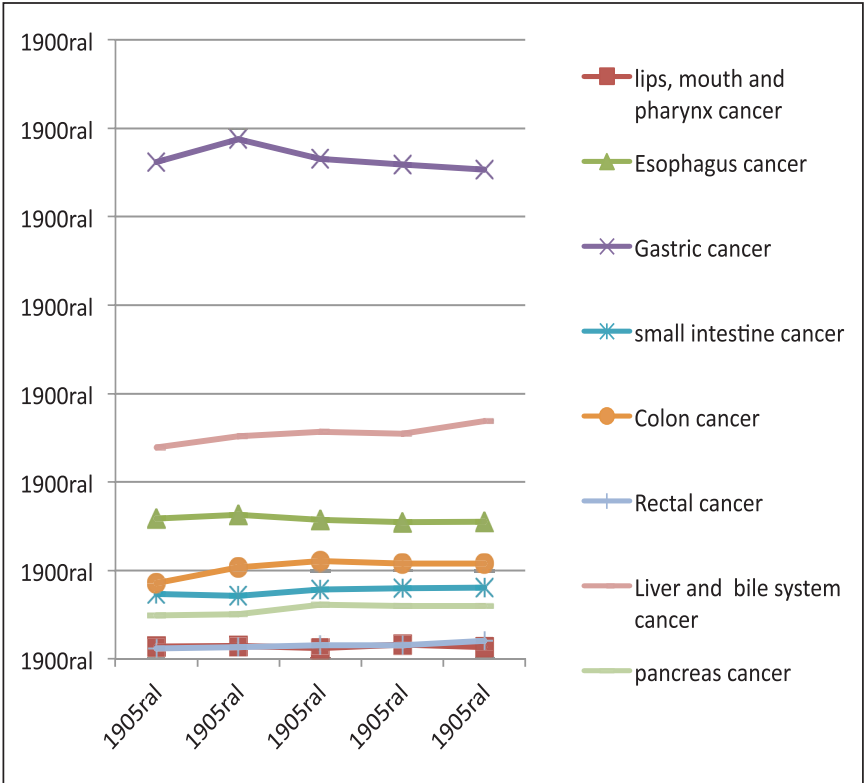

FIGURE 3. Comparison of gastrointestinal cancers incidence trend divided by age groups in 29 provinces of Iran from 2006 to 2010.

\section{DISCUSSION}

The results of this study revealed that the mortality trend of gastric, colorectal, liver and pancreatic cancers had been developing between 2006 and 2010 in Iran. Ganji et al.'s ${ }^{(8)}$ Study in Tehran showed that gastric, hepatobiliary, liver cirrhosis, esophageal and colon cancers were the most important causes of death from gastrointestinal disorders between 2001 and 2005. Different studies show an increasing and decreasing trend of deaths caused by gastric cancer in the world. Bertuccio et al. ${ }^{(9)}$ showed that the trend of deaths caused by gastric cancer has decreased from 1980 to 2005 in western countries, United States and even in high incidence gastric cancer countries like Japan, China, Korea, Colombia, Ecuador and Russia. The result of this decrease is correlated with better food preservation, declined smoking levels, controlling H-pylori infection, especially during childhood and adolescents ${ }^{(9)}$ and improvement of diagnosis and treatment methods ${ }^{(19)}$.

In Center et al.'s study in years 1998 to 2002, the decreasing trend of mortality due to colorectal cancer has been observed in many developed countries all around the world like the United States, Australia, New Zealand, Austria, France, Germany, Ireland and also some of Asian and Eastern European countries like Japan, Czech Republic, Slovakia, Latvia and South Africa by the side of the economy. This decline may be related to early diagnosis by screening ${ }^{(11)}$, better treatment of colorectal cancer and more survival ${ }^{(20)}$. Unlike the decreasing trend of death from gastric and colorectal cancers mentioned in several studies, Pour Hosseingholi et al. ${ }^{(12)}$ showed an increasing trend of gastric and colorectal cancers in Iran during the years 1995 to 2003. Access to colorectal cancers screening in Iran is very poor because of costs and the problems of the health care system ${ }^{(21)}$. This may be effective in the ascending trend of colorectal cancer mortality ${ }^{(12)}$. Some studies have shown that gastric cancer is the main cause of deaths from cancers among Latin American men, Asian countries and Iran ${ }^{(22,23)}$. The results of the present study also showed that among gastrointestinal cancers, the gastric cancer had the highest rate of mortality in Iran during the study years. Most of the gastric cancer sufferers in Iran are in the development stages of the disease and are non-curable ${ }^{(24-26)}$ and their surveillance is rather low ${ }^{(27)}$. Lack of early diagnosis plans for diagnosing gastric cancer patients in the first stages of illness has been effective in increasing mortality trends ${ }^{(12)}$. In their study, they showed that the amount of mortality from liver cancer had been increased from 1999 to 2004 in $\operatorname{Iran}^{(28)}$, which correlates with the results of the present study. The death trend from liver cancer has been heterogeneous in the European countries in 1970 to 1996. The increasing trend of deaths caused by this cancer in some of European countries, like Italy, is due to infection with hepatitis C and better diagnosis of liver cancer in cirrhosis patients ${ }^{(29)}$. The highest rate of liver cancer in East Asian countries is due to the high prevalence of hepatitis B virus ${ }^{(6,30)} .80 \%$ of patients with liver cancer in Iran have been infected with hepatitis $\mathrm{B}^{(31,32)}$. Also, Hajiani et al.'s ${ }^{(33)}$ study in the south of Iran showed that the main cause of liver cancer is hepatitis B and C. Pancreatic cancer is the deadliest cancer among gastrointestinal cancers and only $4 \%$ of sufferers live more than 5 years ${ }^{(34)}$. Hariharan et al. ${ }^{(13)}$ showed an increasing trend of mortality caused by pancreatic cancer in both sexes in Romania, Albania, Spain, Croatia and Korea and decreasing trend of death in Ireland, England, Switzerland, Austria and Poland during 1992 to 2002. In many studies, similar to our study, the correlation between smoking and mortality of pancreatic cancer has been observed ${ }^{(19-21)}$. 
As reported by WHO in 2012, death caused by gastric, colorectal, liver, pancreas and esophagus cancers has been higher in every hundred thousand people in men than women and also the results of this report showed that in Iran, the death due to gastrointestinal cancers was higher among Iranian men than women ${ }^{(15)}$. Also, studies have shown that the trend of mortality from colorectal, gastric, liver and pancreatic cancers is higher in men than women and the number of deaths also increases with ageing ${ }^{(12)}$.

Among the limitations of this study, we can mention low calculation of mortality from cancers in Iran because of the weakness of mortality registration system ${ }^{(22)}$. Also, the results of this study were just related to age and gender data and did not check the mortality trend in different cities of Iran in order to determine the risk full areas by the side of deaths from gastrointestinal cancers. It is suggested that some studies determine the dispersion of deaths caused by these cancers in all parts of Iran in order to be able to design the needed plans in health and treatment field more efficiently. The epidemiological studies such as studying the time trend of disease outbreak and mortality and disability from them in different countries of the world cause the emergence of differences and similarities due to the comparison of their results. Consequently, these varieties are a probe for finding the results. For instance, by considering the increasing trend of deaths caused by gastric and colorectal cancers in Iran and comparing it with a decreasing trend of deaths from these cancers in developed countries, we should improve the existing diagnosis, treatment and preventive methods in Iran in comparison with different areas. Correction of lifestyle, educational methods for prevention and screening has definitely a significant effect on achieving the expected goal.

\section{ACKNOWLEDGEMENTS}

The authors wish to thank Dr. Nasrin Shokrpour at the Research Consolation Centre (RCC) at Shiraz University of Medical Sciences for her invaluable assistance in editing this manuscript, and Mr. A. Azizian from Department of Epidemiology, Shiraz University of Medical Sciences, Shiraz, Iran for his technical advice.

\section{Authors' contribution}

Salehi F: idea of study. Ahmadi Soodejani S S: data collection. Ahmadi A: statistical analysis. Shahini Shams Abadi M: writing of text.

Salehi F, Ahmadi A, Ahmadi Soodejani S S, Shahini Shams Abadi M. A mudança da tendência de mortalidade causada por câncer gastrointestinal no Irã durante os anos 2006-2010. Arq Gastroenterol. 2018,55(3):237-41.

RESUMO - Contexto - O câncer é uma das causas mais importantes de morte no mundo. De acordo com a sua alta incidência e mortalidade, o câncer gastrointestinal tem particular importância entre outros tipos de neoplasias. Objetivo - Este estudo foi conduzido para investigar as tendências de mudança de mortalidade de câncer gastrointestinal no Irã. Métodos - Foi realizada pesquisa analisando-se os dados de mortalidade relatados em 29 províncias do Irã entre 2006-2010. A tendência de mortalidade de câncer gastrointestinal foi delineada para ambos os sexos nos anos de estudo e desagregadas por grupos etários em sua distribuição de frequência. O software WinPepi foi usado para análise. Resultados - Nos anos 2006-2010, a taxa de mortalidade por câncer gástrico, colorretal, de fígado e pancreático aumentou significativamente. A mortalidade por câncer gastrointestinal é maior nos homens do que nas mulheres e, além disso, os resultados mostraram que com o aumentar a idade, a morte causada por estes cânceres também aumentou. Conclusão - As causas mais importantes da morte entre cânceres de origem gastrointestinal no Irã foram o gástrico, o hepático e o colorretal e devido a sua tendência crescente no país, a realização de intervenções preventivas para os fatores de risco é necessária.

DESCRITORES - Neoplasias gastrointestinais, mortalidade. Fatores etários. Fatores sexuais. Oriente Médio.

\section{REFERENCES}

1. Jemal A, Bray F, Center MM, Ferlay J, Ward E, Forman D. Global Cancer Statistics. CA Cancer J Clin. 2011;61:69-90.

2. Pisani P, Parkin DM, Bray F, Ferlay J. Estimates of the worldwide mortality from 25 cancers in 1990. Int J Cancer. 1999;83:18-29.

3. Khosravi A, Aghamohamadi S, Kazemi E, Pour Malek F, Shariati M. Mortality profile in Iran (29 provinces) over the years 2006 to 2010. Tehran: Ministry of Health and Medical Education. 2013:3-21.

4. Ma X, Yu H. Cancer issue: global burden of cancer. Yale J Biol Med. 2006; 79:85-94.

5. Sadjadi A, Nouraie M, Mohagheghi MA, Mousavi-Jarrahi A, Malekezadeh R, Parkin DM. Cancer occurrence in Iran in 2002, an international perspective. Asian Pac J Cancer Prev. 2005; 6:359-63.

6. Ferlay J, Shin HR, Bray F, Forman D, Mathers C, Parkin DM. Estimates of worldwide burden of cancer in 2008: GLOBOCAN 2008. Int J Cancer. 2010;127:2893-917.

7. Naghavi M. Transition in health status in the Islamic Republic of Iran. Iran J Epidemiol. 2006;2:45-57.

8. Ganji Azita, Safavi Mohsen, Nouraei Mahdi, Naseri Moghadam S, Merat SH, Vahedi H, Malekzadeh R. Digestive and liver diseases statistics in several referra centers in Tehran, 2000-2004. Govaresh. 2006;11:33-8.

9. Bertuccio P, Chatenoud L, Levi F, Praud D, Ferlay J, Negri E, et al. Recent patterns in gastric cancer: a global overview. International journal of cancer. 2009;125:666-73.

10. Méndez-Sánchez N, Villa AR, Vázquez-Elizondo G, Ponciano-Rodríguez G, Uribe M. Mortality trends for liver cancer in Mexico from 2000 to 2006. Ann Hepatol. 2008;7:226-9.
11. Center MM, Jemal A, Smith RA, Ward E. Worldwide variations in colorecta cancer. CA Cancer J Clin. 2009;59:366-78.

12. Pourhoseingholi M, Faghihzadeh S, Hajizadeh E, Gatta G, Zali M, Abadi A. Trend analysis of gastric cancer and colorectal cancer mortality in Iran, 19952003. Iran J Cancer Prev. 2011;4:38-43.

13. Hariharan D, Saied A, Kocher H. Analysis of mortality rates for pancreatic cancer across the world. HPB (Oxford). 2008;10:58-62.

14. Bosetti C, Malvezzi M, Chatenoud L, Negri E, Levi F, La Vecchia C. Trends in cancer mortality in the Americas, 1970-2000. Ann Oncol. 2005;16:489-511.

15. International Agency for Research on Cancer (IARC), World Health Organization (WHO). GLOBOCAN 2012: estimated cancer incidence, mortality and prevalence worldwide in 2012. [Accessed 2017 Sept 14]. Available from: http://globocan.iarc. fr/Pages/fact_sheets_cancer.aspx.

16. Goh K. Changing trends in gastrointestinal disease in the Asia-Pacific region. J Dig Dis. 2007;8:179-85.

17. Singh GK, Siahpush M, Altekruse SF. Time trends in liver cancer mortality, incidence, and risk factors by unemployment level and race/ethnicity, United States, 1969-2011. J Community Health. 2013;38:926-40.

18. Boyle P, Maisonneuve P, Bueno de Mesquita B, et al. Cigarette smoking and pancreas cancer: A case-control study of the search programme of the IARC. Int J Cancer. 1996;67:63-71.

19. Shibata A, Parsonnet J. Stomach cancer. In: Schottenfeld D, Fraumeni JF, Jr, eds. Cancer Epidemiology and Prevention. Vol. 3. New York: Oxford University Press, 2006: 707-20. 
20. Ribes J, Navarro M, Cleries R, Esteban L, Pareja L, Binefa G, et al. Colorectal cancer mortality in Spain: trends and projections for 1985-2019. Eur J Gastroenterol Hepatol. 2009;21:92-100.

21. Ansari R, Mahdavinia M, Sadjadi A, Nouraie M, Kamangar F, Bishehsari F, et al. Incidence and age distribution of colorectal cancer in Iran: results of a population-based cancer registry. Cancer Lett. 2006;240:143-7.

22. Sadjadi A, Malekzadeh R, Derakhshan MH, Sepehr A, Nouraie M, Sotoudeh M, et al. Cancer occurrence in Ardabil: Results of a population-based Cancer Registry from Iran. Int J Cancer. 2003;107:113-8.

23. Malekzadeh R, Derakhshan MH, Malekzadeh Z. Gastric cancer in Iran: epidemiology and risk factors. Arch Iran Med. 2009;12:576-83.

24. Somi MH, Farhang S, Mirinezhad SK, Naghashi S, Seif-Farshad M, Golzari M. Cancer in East Azerbaijan, Iran: results of a population-based cancer registry. Asian Pac J Cancer Prev. 2008;9:327-30.

25. Malekzadeh R, Naseri Moghadam S. Commented summaries from current medical literature; reducing gastric cancer mortality in developing countries: learning from the experience in Japan. Arch Iran Med. 2008;11:588-90.

26. Moghimi-Dehkordi B, Safaee A, Zali MR. Survival rates and prognosis of gastric cancer using an actuarial life-table method. Asian Pac J Cancer Prev. 2008;9:317-21.
27. Movahedi M, Afsharfard A, Moradi A, Nasermoaddeli A, Khoshnevis J, Fattahi F, Akbari ME. Survival rate of gastric cancer in Iran. J Res Med Sci. 2009;14: 367-73.

28. Fazli Z, Fatemeh S, Abdi A, Pourhosseingholi M, Taghinejad H. Studying of liver cancer mortality and morbidity burden in Iran. Sci J Ilam Univ Med Sci. 2012;4:117-22.

29. La Vecchia C, Lucchini F, Franceschi S, Negri E, Levi F. Trends in mortality from primary liver cancer in Europe. Eur J Cancer. 2000;36:909-15.

30. Jemal A, Bray F, Center MM, Ferlay J, Ward E, Forman D. Global cancer statistics. CA Cancer J Clin. 2011;61:69-90.

31. Merat S, Malekzadeh R, Rezvan H, Khatibian M. Hepatitis B in Iran. Arch Iran Med. 2000;3:192-201

32. Shamszad M, Farzadegan H. Hepatitis B related cirrhosis and hepatocellular carcinoma in Iran. J Iran Med Council. 1982;8:228-33.

33. Hajiani E, Masjedizadeh R, Hashemi J, Azmi M, Rajabi T. Risk factors for hepatocellular carcinoma in Southern Iran. Saudi Med J. 2005;26:974-7.

34. Costa P. Medical position statement: epidemiology, diagnosis, and treatment of pancreatic ductal adenocarcinoma. Gastroenterology. 1999;117:1463-84. 